\title{
Model of Students' Project Skills Development in the Corporate Educational Cooperation
}

\author{
Victoria Dodrova \\ Department of Foreign \\ Languages \\ Samara State Technical \\ University \\ Samara, Russia \\ victoria_dob@mail.ru
}

\author{
Eugenia Yelizarova \\ Department of Foreign \\ Languages \\ Samara State Technical \\ University \\ Samara, Russia
}

\author{
Polina Labzina \\ Department of Foreign \\ Languages \\ Samara State Technical \\ University \\ Samara, Russia \\ labzinapg@mail.ru
}

\author{
Natalia Ageenko \\ Department of Foreign \\ Languages \\ Samara State Technical \\ University \\ Samara, Russia
}

\begin{abstract}
In the paper the students' project activity development in the process of corporate educational cooperation is considered. The structural and functional model of the project skills formation is suggested on the basis of the research carried by the Department of Foreign Languages of Samara State Technical University. Such notions as project-based activity, project, project team, model, process, development, educational cooperation are analyzed and discussed as well as the approaches, stages, methodological bases, laws and conditions of project activity realization. On the basis of the chosen criteria of the formed project skills the indicators of the levels of the project skills development are defined and the characteristics of the main steps of the project activity are given. (Abstract)
\end{abstract}

Keywords - project activity, project skills, model, process, development (key words)

\section{INTRODUCTION}

Nowadays education exists in a rapidly changing environments. The modern Russian society needs graduates and future specialists to be capable of solving complex problems, finding fundamentally new creative solutions, responding to the challenges of the time. These changes and demands have a dramatic impact on the modernization of the national education system, proclaiming the priority of freedom and creativity of the self-developing personality.

In the modern world useful life skills and practical real world experience have become an absolute necessity for most people. These skills include communication skills, management skills, cooperative skills, research skills, etc. Accordingly, it is an important task for every teachers to improve their students' skills in real-life situations, to give them an opportunity to use acquired skills in a creative and meaningful way. Obviously all these skills can best be developed through project work. That is why in teaching methodology the concept of project activity or project-based learning has recently gained a special significance.

The idea of the project activity has a great potential for self-development, development of intellectual and creative abilities of the individual: at present, project activity is actualized in many educational areas. It stimulates cognitive activity, independence, creative approach to mastering educational material, encourages the person to self-education. Project activity is an important indicator of the effectiveness of the educational process. However, to master the project activity it is necessary to form special project skills that have personal significance for students and determine the productivity, quality and speed of mastering the project activity.

As a result of transforming the personal experience of students and schoolchildren, positive conditions are created for the development of general educational and special skills necessary for effective personal development. At the same time, the development of the personality is impossible outside the society, outside the relationships that are formed within it as a result of corporate educational interaction.

\section{RESEARCH}

In the course of our research, the structural and functional model of students' project skills development in the corporate educational cooperation was formed. The study was conducted in 2014-2017 on the basis of the Department of Foreign Languages of Samara State Technical University. The experimental group included bachelor students of Samara State Technical University.

We chose modeling as the scientific method of research, and our task was to develop a model of the project skills development.

\section{A. Terms}

Let us consider several notions important for the understanding of our research.

To start with, the conducted analyses of the pedagogical literature showed that the notion of "pedagogical project" usually includes the notions of learning strategies, project ideas, project approach, as well as the idea of a project as paradigm, a learning organizational form and a method. G.Hegedüs, for example, defines project pedagogy as a learning-teaching strategy which means working on a task or problem which is perceived by the learners as one of their own 
[1]. On the other hand English researchers define the term as a teaching method in which students gain knowledge and skills by working for an extended period of time to investigate and respond to a complex question, problem, or challenge [2].

These definitions of project pedagogy is a better description of what a project actually is. A project is defined as supplementary, long-term educational assignment necessitating personal initiative, undertaken by an individual student or a group of students [3].

Project activity is a teaching method in which students gain knowledge and skills by working for an extended period of time to investigate and respond to a complex question, problem, or challenge [4]. This may include a single project or a series of projects that require students to use various skillssuch as interviewing, collaborating, researching, writing, or public speaking - to produce various work products, such as research papers, scientific studies, public-policy proposals, multimedia presentations, art installations, or musical and theatrical performances, for example [5].

The key elements of project activity were described by Mária Füz-Kószó and Klára Szabó:

Key knowledge, understanding and skills: project activity is focused on student learning goals, including standards-based content and skills such as critical thinking, problem solving, collaboration, self-management, etc.

Challenging problem, task or question: project activity is framed by a meaningful problem to solve at the appropriate level of challenge.

Sustained inquiry: students engage in a rigorous, extended process of asking questions, finding resources, and applying information.

- $\quad$ Student-oriented activities: students make some decisions about the project, including how to work and what to create.

- $\quad$ Authenticity: project activity features real-world context, tools, quality standards, or impact to students' personal concerns and interest in their lives.

- $\quad$ Reflection: students and teachers reflect on learning, the effectiveness of their inquiry and project activities, the quality of student work, obstacles and how to overcome them.

Critique and revision: students give, receive and use feedback to improve their process and products.

- Public Product: students make their project work public by displaying or presenting it to people before and beyond the classroom [6].

Dr. Jessica Spallino suggest the following graph that outlines some critical elements for the implementation of project based learning (see Fig. 1):

\footnotetext{
- Daily;

- Data Focused;

- Consistent;

- Collaborative;

- Real World;

- Personal;

- Organized.
}

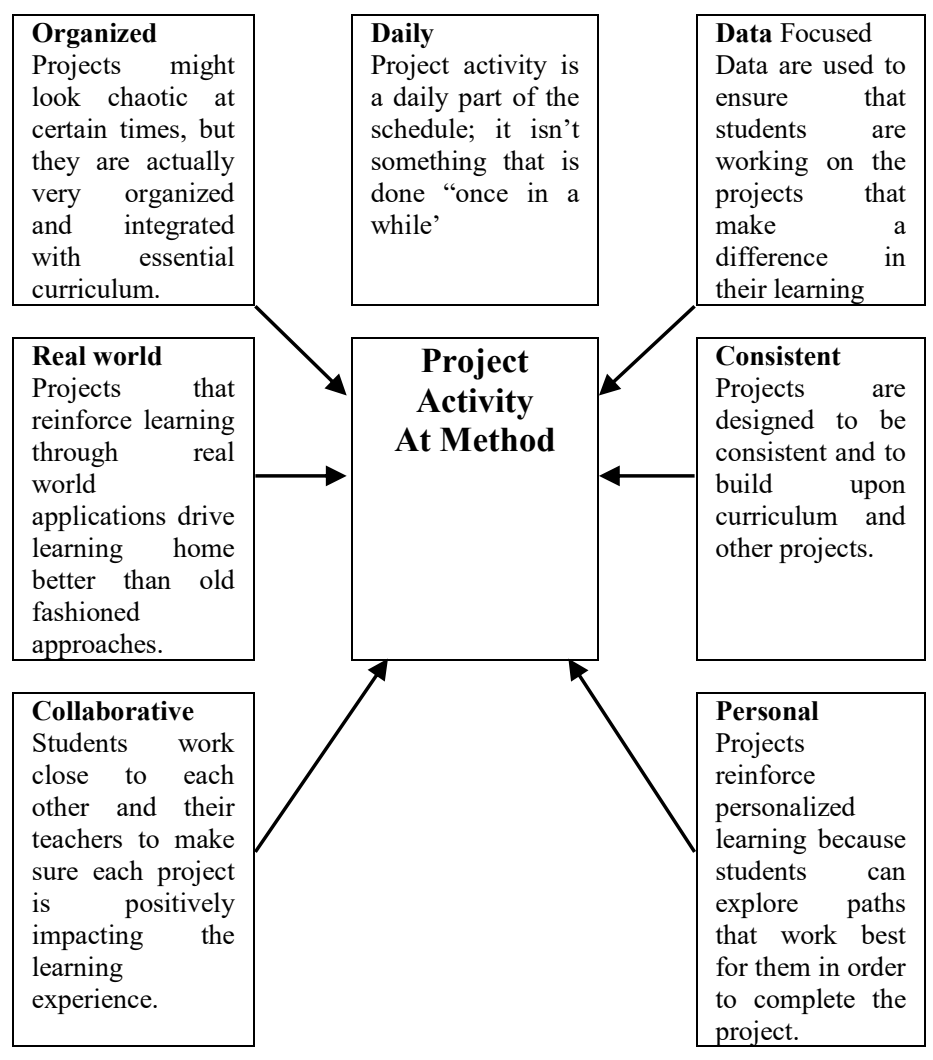

Fig. 1. Elements for the project based learning implementation [7]

We should also define the notion of a "project team". The project team is the so-called task group since it is created for a specific task accomplishment, it tends to have a limited life span, the duration of the project.

In the most general form, the term "model" is defined as a system of elements that reproduces certain aspects, connections, functions of the subject of research [8]. It is a simulation of a real-world situation or environment. We rely on the interpretation given by A.I. Uyemov who defines "model" as a system, the study of which serves as a means for obtaining information about another system [9]. The normative model is defined by him as an abstract prototype of the activity that needs to be implemented in the future, that also contains a general idea of what needs to be done to achieve the best results. Such a substitution becomes possible only if the real object of study, as well as the model - the product of its analysis - are similar in certain respects.

G.E. Muravyova believes that the model always performs a cognitive role, acting as a means of explanation and prediction [10]. The method of modeling, being by its nature a procedure carried out on the basis of abstract-logical thinking, involves the possibility of constructing speculative models in its theoretical part with the help of other research procedures.

The practical and cognitive value of the model in any study (e.g. $[11 ; 12]$ ) is mainly determined by its adequacy to the studied object, as well as by how correctly the main principles of modeling (visibility, certainty, objectivity) are 
taken into account at the stages of the model construction. Thus they mainly determine the possibilities and the type of the model, as well as its functions in the study.

The concept of "process" is considered according to S.L. Rubinshtein and B.F. Lomov as the successive change of phenomena, their states, as a combination of a sequence of actions to achieve any result, as the regular, consistent, continuous change of successive moments of development. The procedural character of personality development was stressed by B.F. Lomov [13]. According to S.L. Rubinstein, the continuity of the psychic is objectively determined by its leading role in the self-regulation of the entire life of people [14].

The pedagogical process is the cooperative way of students and learners towards goals mediated by the content and methods of its assimilation and performed in a sociocultural environment. In this process, there is a constant need to relate the teacher's direction to the activity and independence of the student.

The term "development" today has a lot of notation. With regard to man in most cases, it is defined as giving the final form, achieving full maturity, final development. Development is defined as the gradual creation of operant behavior (behavior that is characterized by environmental impact, as a result of which necessary changes take place), by reinforcing successive steps that approximate the desired result.

According to N.F. Talyzina, "development" is an activity connected with the organization of the assimilation of a certain element of social experience (concept, action) by the student. Both "development" and "training" are related to the activities of the teacher, but their content differs. First, the concept of "training" is broader than the concept of "development". The term "development" is usually used when it comes to what the student is getting: concept, skill, new activity [15].

In this context L.B. Sokolova points out that even if knowledge and skills are formed in the learning process, and thus the student's personality is developed, we cannot surely assert that "personality is formed", as the more it is formed, the more it resists any "development" [16]. Therefore, we assume that education oriented to personal development achieves its goals to the extent that it creates the situation of the person's demand for self-development. The teacher acting in accordance with the norms of culture is not engaged in the personality development, but he creates conditions for the fullscale manifestation and accordingly development of the personality functions of the subject in this activity.

In our opinion, the development deepens the phenomenon of development, which is determined by the circumstances of a person's life, by his activity, by purposeful processes of upbringing and education. Unlike the purposeful, organized education process, development also includes many external, objective and internal, subjective factors that spontaneously affect the individual, including the activities of the teacher or coordinator.

\section{B. Approaches}

The effectiveness of student's project activity development is largely determined by the approaches, laws and principles that make up the methodological basis of scientific psychological and pedagogical research.

We consider the system and activity approaches to be the leading methodological basis for identifying the patterns of the process of project skills development. Thus the main external and internal links of the project skills development can be considered as an integral phenomenon formed in the framework of a specially organized activity.

The implementation of the system approach allows us to describe the following patterns of project activity organization:

1. Relationship of project activities and social environment.

2. Relationship of project activities and personal activity.

3. Relationship of project activities and communication.

4. Relationship of project activities and creativity.

5. Relationship of project activity and knowledge value.

These laws, being the necessary and essential links, characterize the conditions for project activity organization as a psychological and pedagogical phenomenon. As it is proved by the pedagogical surveys, the organization of the project skills development cannot be effective without taking the above-mentioned conditions into account.

To understand the essence of the pedagogical conditions of student's project activity development, the following statements of the pedagogical theory of activity expressed by G.I. Shchukina are of great importance:

- the development of activities in the educational process marks the progressive development of the personality. On the basis of the activity and attitudes towards it, consistent development of personality traits takes place, such as cognitive interest, activity, independence;

- the development of inter-subject relations between the teacher and the student is characterized by the more active position of the student in the educational process, which is conditioned by independence, goal-setting, reflection;

- the change in the nature of the activity significantly affects the change in the position of the student: from the performer to the active one, that is to the position of the subject [17].

On the bases of our analysis and the above-mentioned statements, we concluded that the project activity plays an important role in the development of the personality. That is why, we consider the following pedagogical conditions as the most effective for the student's project activity development:

- the organization of corporate educational interaction, going back from dialogical forms to the group and team ones;

the orientation of the educational process on the development of the student's value relation to the project activity that ensures the student's subject position in mastering it;

- a step-by-step complication of the project assignments content, that means the shift of the emphasis from reproductive activity to creative work.

Our experiment showed that the driving force in the change of stages is the cognitive motivation. 


\section{Criteria of the Project Skills Development}

The content, structure and functional components of the project activity influenced the choice of a system of criteria for the project skills development (motivation and value, cognitive, operational, reflexive and evaluative) and allowed us to determine the indicators for the evaluation of the level of project skills development.

The motivation and value component is determined by the system of motives and the needs for cognition; the doctrine is realized as a value, and the personality is a project that creates itself in the process of free choice of needs satisfaction. The content of the chosen criteria and level indicators are presented in Table 1.

TABLE 1. Motivation and value characteristics of the project skills development levels.

\begin{tabular}{|c|c|c|c|}
\hline \multirow{2}{*}{ Indicators } & \multicolumn{3}{|c|}{ Levels } \\
\hline & Optimal & Sufficient & Low \\
\hline $\begin{array}{l}\text { - students realize } \\
\text { the project } \\
\text { activity as value } \\
\text {-students are } \\
\text { interested in the } \\
\text { projecting of } \\
\text { their own } \\
\text { activities, self- } \\
\text { development, } \\
\text { self-organization }\end{array}$ & $\begin{array}{l}\text { Prevailing } \\
\text { orientation to self- } \\
\text { development. Steady } \\
\text { interest to the } \\
\text { projecting of their } \\
\text { own activities and } \\
\text { self-organization. }\end{array}$ & $\begin{array}{l}\text { Steady interest } \\
\text { to the } \\
\text { discovery of } \\
\text { their own } \\
\text { methods of } \\
\text { activity, to the } \\
\text { projecting of } \\
\text { their own } \\
\text { activities. }\end{array}$ & $\begin{array}{l}\text { Situational } \\
\text { interest to the } \\
\text { project } \\
\text { activities. }\end{array}$ \\
\hline
\end{tabular}

The most important characteristic feature of project activity is that social and personal motives are dominant in it. Mária Füz-Kószó and Klára Szabó define the following sources of motivation:

- Theme: students are engaged in doing a task or solving a problem (upon their own initiative). The theme chosen by them is naturally interesting for them, so they are motivated.

- Team: in team work the tasks and reponsibilities are divided between team members so that each student is able to find a task which is motivating for him. It is extremely motivating that learners work together with people they like and they work toward a common goal.

- Product or achievement: student use their own ideas and creativity to bring about something new and exciting. The source of information is their own experience, they do not work toward a grade but they work for a product or achievement that is directly linked to their own lives and sphere of activities.

- Activity: project activites free both the teacher and the student from the strict discipline and immovabilities of the classroom, as well as the rigid nature of the curriculum.

- Recognition: it is important to recognize project work from the very beginning to the very end. Thus, small tasks performed successfully by teams or individual learners during any of the stages of project work need to be recognized. During project work self-reflection is important, too, because it teaches the know-how of self-assessment.[6]

The cognitive component as the generalized methods of teaching activity contains a system of knowledge of project skills on goal-setting, design, planning, self-regulation of the project activity - on how to determine what to teach, how to work with the teaching material, how to control the dynamics of your own progress at the level of mastering the substantive and procedural aspects of cognition (see Table 2).

TABLE 2. Cognitive characteristics of the project skills development levels.

\begin{tabular}{|l|l|l|l|}
\hline \multirow{2}{*}{ Indicators } & \multicolumn{3}{|c|}{ Levels } \\
\cline { 2 - 4 } Students & \multicolumn{1}{|c|}{ Optimal } & \multicolumn{1}{c|}{ Sufficient } & \multicolumn{1}{c|}{ Low } \\
understand: & Reflexive, deep, & Deep, & Formal \\
- generalized & conscious, & conscious, & knowledge of \\
methods of & systematic & systematic & the methods \\
project activity; & methods of project & $\begin{array}{l}\text { knowledge on } \\
\text { the methods of }\end{array}$ & of learning \\
activity (at \\
-the teaching as & activity; on goal- & project & the level of \\
an activity: on & setting, design, & activity at the & "recognition" \\
goal-setting, & planning, reflection, & level of & and "repro- \\
design, planning, & self-regulation of & "application". & duction"). \\
reflection, self- & activities. & Reflexive & Fragmentary \\
regulation; & & knowledge on & information \\
- self- & & goal-setting, & on planning, \\
organization & & design, & design. \\
process. & & planning, & \\
& & performance & \\
& & of activities. & \\
\hline
\end{tabular}

The operational component reflects the practical readiness of the student to design and implement independent cognitive activity and contains a system of project skills that help to recognize problems and solve them not only in the process of developing and implementing the project, but also in the process of its adjusting (see Table 3 ).

TABLE 3. Operational characteristics of the project skills development levels.

\begin{tabular}{|c|c|c|c|}
\hline \multirow{2}{*}{ Indicators } & \multicolumn{3}{|c|}{ Levels } \\
\hline & Optimal & Sufficient & Low \\
\hline $\begin{array}{l}\text { Students use: } \\
\text { - project skills; } \\
\text {-algorithm of } \\
\text { designing and } \\
\text { implementing } \\
\text { activities: } \\
\text { methods of } \\
\text { recognizing and } \\
\text { analyzing the } \\
\text { problem, } \\
\text { formulating the } \\
\text { hypothesis, } \\
\text { methods of goal- } \\
\text { setting, } \\
\text { planning, } \\
\text { forecasting and } \\
\text { evaluation of } \\
\text { performance; } \\
\text { methods of self- } \\
\text { regulation and } \\
\text { reflection of } \\
\text { activity. }\end{array}$ & $\begin{array}{l}\text { Use of project skills. } \\
\text { Creative approach to } \\
\text { understanding and } \\
\text { solving of problems. }\end{array}$ & $\begin{array}{l}\text { Reflexive } \\
\text { mastery of } \\
\text { project skills: } \\
\text { recognize } \\
\text { problems, } \\
\text { solve non- } \\
\text { standard } \\
\text { problems, } \\
\text { develop a } \\
\text { project, create } \\
\text { their own } \\
\text { algorithm of } \\
\text { activity. }\end{array}$ & $\begin{array}{l}\text { Under- } \\
\text { standing and } \\
\text { implement- } \\
\text { tation of the } \\
\text { assigned } \\
\text { learning task } \\
\text { according to } \\
\text { the } \\
\text { instruction } \\
\text { or to the } \\
\text { sample. }\end{array}$ \\
\hline
\end{tabular}

The reflexive and evaluative component demonstrates personal attitude to the course and results of the project activity, orientation to the conscious development of independent critical thinking that does not accept dogmas, developing by imposing new information on personal life experience. Evaluation can provide valuable data in terms of the degree to which the planned outcomes were achieved. It can also provide feedback through which future changes can be developed and analyzed. (see Table 4). 
TABLE 4. Reflexive and evaluative characteristics of the project skills development levels.

\begin{tabular}{|c|c|c|c|}
\hline \multirow{2}{*}{ Indicators } & \multicolumn{3}{|c|}{ Levels } \\
\hline & Optimal & Sufficient & Low \\
\hline $\begin{array}{l}\text { Students can: } \\
\text {-think critically } \\
\text { - strive for } \\
\text { evidence } \\
\text {-prove their } \\
\text { position } \\
\text {-cooperate } \\
\text {-esteem } \\
\text { themselves } \\
\text { adequately. }\end{array}$ & $\begin{array}{l}\text { Critical analysis and } \\
\text { comprehension of } \\
\text { incoming } \\
\text { information. } \\
\text { Specification of } \\
\text { their knowledge. } \\
\text { Self-analysis, self- } \\
\text { determination. }\end{array}$ & $\begin{array}{l}\text { Aiming at } \\
\text { dialogue, self- } \\
\text { diagnosis in } \\
\text { relation to the } \\
\text { development } \\
\text { of different } \\
\text { skills and } \\
\text { qualities, } \\
\text { openness to } \\
\text { the new } \\
\text { information. } \\
\text { Adequate self- } \\
\text { esteem. }\end{array}$ & $\begin{array}{l}\text { The lack of } \\
\text { self-analysis, } \\
\text { self- } \\
\text { evaluation } \\
\text { in the } \\
\text { comprehen- } \\
\text { sion of } \\
\text { specific } \\
\text { values, non- } \\
\text { productive } \\
\text { style of } \\
\text { thinking. }\end{array}$ \\
\hline
\end{tabular}

\section{Stages}

According to G.Hegedűs, project work has the following stages:

- choice of topic;

- planning (formulation of goals and tasks);

- organization;

- data collection;

- elaboration of topic;

- creation of the product, in a form, which is suitable to go public;

- project evaluation, correction;

- publishing project results and end products;

- closing events [6].

To explain the mechanism of the student's transition from one level of mastering the skills to the other, we used the following technological cycle, shown in Fig. 2::

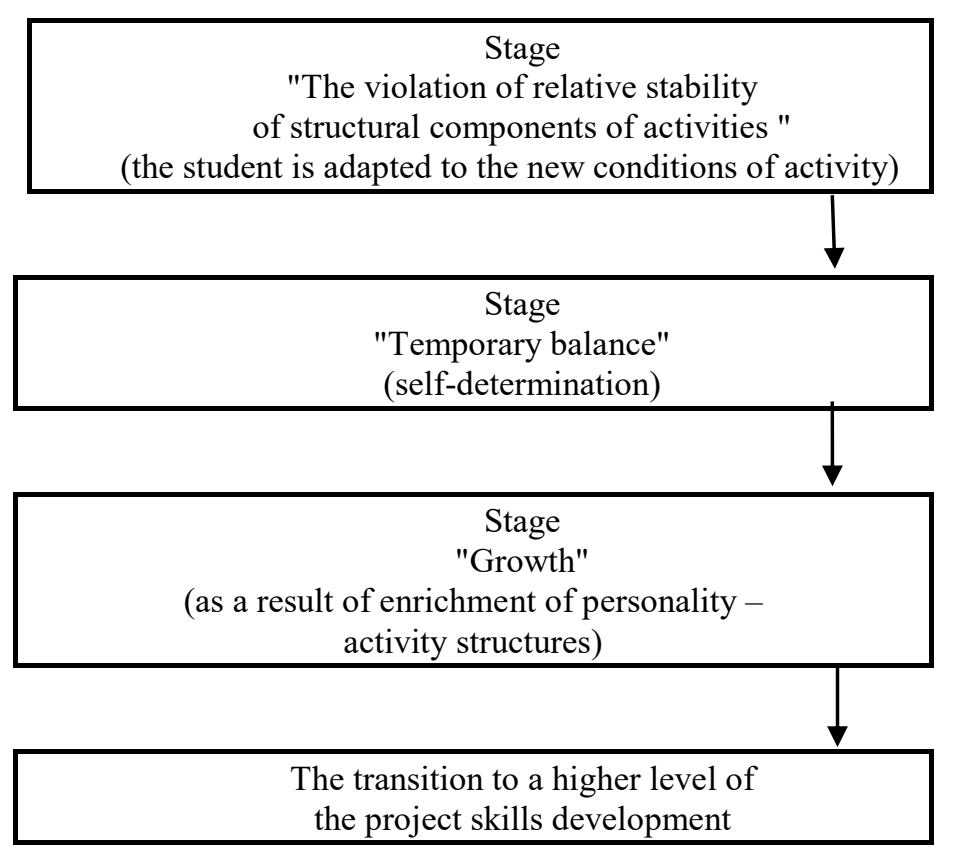

Fig. 2. Technological cycle of project skills development
The comparative analysis and generalization of various approaches allowed us to determine the three stages of the process of the students project activity:

1. organizational and preparatory, involving the search and analysis of the problem situation, identifying the problem of the project, determining its purpose, planning for the forthcoming activity. The major outcome of the planning, after gathering all necessary information, is the setting of goals for the project and determining of objectives.

2. technological, associated with the search for the optimal solution of the project problem in accordance with the goal. Time limits, schedules, performance standards, and other techniques serve as major checkpoints to trigger action if necessary to keep things on course. The teacher/ coordinator thus sets up ways to check the progress towards the objectives and goals.

3. final, during which the project is being implemented (presented), a collective and individual assessment of the project activity and its results.

At all the stages of the project activity, the teacher / project coordinator acts as a facilitator of the students' cognitive activity. Based on the study of the subject experience and cognitive interests of the students, the teacher develops an individualized motivation for their activities through the necessary consulting assistance and use of various methods (suggestive questions and situations, group discussions, brainstorming, round table discussions, "public presentation") and means of activation (audio and video recordings, slides).

The highlighted essential features of the organizational, preparatory, technological and final stages of the project activity of students aimed at clarifying its essence as a special kind of cognitive activity of students.

The organizational and preparatory stage results in students' positive motivation to the project activities. The student realize the importance of design skills in terms of improving the educational process.

As a result of the technological stage the students realize the importance of project activity for the organization and correction of independent cognitive activity.

At the end of the final stage the students develop individual systems of methods of the project activity development and self-realization in educational activities.

To check the progress and quality of the skills acquired the following diagnostic methods may be used on all the stages:

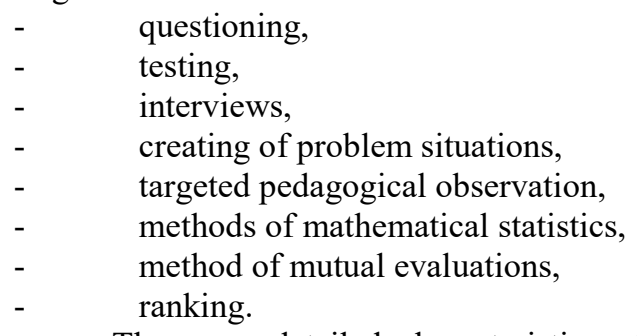

The more detailed characteristics of every stage are presented in Tables 5 - 7. 
TABLE 5. Characteristics of the Organizational and preparatory stage of students' project activity

\begin{tabular}{|c|c|c|}
\hline Activity description & Students' activity & $\begin{array}{c}\text { Project coordinator's } \\
\text { activity }\end{array}$ \\
\hline $\begin{array}{l}\text { - search and analysis } \\
\text { of the problem } \\
\text { situation; } \\
\text {-realization of the } \\
\text { problem of the project; } \\
\text {-definition of the goal, } \\
\text { objectives and theme } \\
\text { of the project; } \\
\text { - determination of the } \\
\text { necessary sources of } \\
\text { information, methods } \\
\text { and means of design, } \\
\text { ways of presenting the } \\
\text { results and criteria for } \\
\text { their evaluation; } \\
\text {-distribution of tasks } \\
\text { (duties) between the } \\
\text { members of the } \\
\text { project team (in case } \\
\text { of group project) }\end{array}$ & $\begin{array}{l}\text {-search or } \\
\text { selection (from } \\
\text { the proposed list) } \\
\text { of the problem } \\
\text { situation, its } \\
\text { analysis; } \\
\text { - discussion of the } \\
\text { project problem } \\
\text { with the } \\
\text { coordinator and } \\
\text { peers; } \\
\text {-analysis and } \\
\text { clarification of the } \\
\text { available } \\
\text { information, } \\
\text { search for } \\
\text { additional } \\
\text { information; } \\
\text {-formulation of } \\
\text { the goal, } \\
\text { objectives and } \\
\text { themes of the } \\
\text { project; } \\
\text {-planning of the } \\
\text { project activities } \\
\text { implementation ; } \\
\text {-discussing the } \\
\text { project evaluation } \\
\text { criteria with the } \\
\text { teacher / } \\
\text { coordinator }\end{array}$ & $\begin{array}{l}\text { - study of subject } \\
\text { experience and } \\
\text { cognitive interests of } \\
\text { students; } \\
\text {-motivation for } \\
\text { project activities; } \\
\text {-creation of a } \\
\text { problem situation } \\
\text { and organization of } \\
\text { its discussion; } \\
\text { - observation and } \\
\text { counseling of } \\
\text { students (suggesting } \\
\text { ideas, making } \\
\text { assumptions) in the } \\
\text { project activities } \\
\text { planning; } \\
\text {-organization of the } \\
\text { discussion of criteria } \\
\text { for the project } \\
\text { evaluation }\end{array}$ \\
\hline
\end{tabular}

TABLE 6. Characteristics of the Technological stage of students' project activity

\begin{tabular}{|c|c|c|}
\hline Activity description & Students' activity & $\begin{array}{c}\text { Project coordinator's } \\
\text { activity }\end{array}$ \\
\hline $\begin{array}{l}\text { - collection and } \\
\text { analysis of } \\
\text { information on the } \\
\text { project problem; } \\
\text {-search and } \\
\text { evaluation of } \\
\text { possible } \\
\text { solutions of the } \\
\text { project problem; } \\
\text {-presentation of the } \\
\text { optimal solution of } \\
\text { the project problem } \\
\text { in graphical or } \\
\text { verbal form }\end{array}$ & $\begin{array}{l}\text {-search and analysis } \\
\text { of information on } \\
\text { the project problem; } \\
\text {-analysis and } \\
\text { assessment of the } \\
\text { possible } \\
\text { solutions of the } \\
\text { project problem; } \\
\text { - selection of the } \\
\text { optimal solution of } \\
\text { the project } \\
\text { problems, its } \\
\text { presentation in } \\
\text { graphical or verbal } \\
\text { form }\end{array}$ & $\begin{array}{l}\text {-stimulating search } \\
\text { and } \\
\text { discussing possible } \\
\text { solutions of the project } \\
\text { problem; } \\
\text {-consulting assistance } \\
\text { in their analysis and } \\
\text { evaluation; } \\
\text { - observation of the } \\
\text { progress in the } \\
\text { implementation of } \\
\text { project activities; } \\
\text {-development of } \\
\text { competencies and } \\
\text { cognitive interests of } \\
\text { students }\end{array}$ \\
\hline
\end{tabular}

TABLE 7. Characteristics of the Final stage of students' project activity

\begin{tabular}{|l|l|l|}
\hline Activity description & Students' activity & $\begin{array}{c}\text { Project coordinator's } \\
\text { activity }\end{array}$ \\
\hline - realization of the & - implementation & -consulting students; \\
project and & and presentation of & -organizing public \\
presentation of its & the project (public & presentation and \\
results in the form of & presentation, report); & discussion of the \\
a written or oral & - participation in the & project; \\
report; & group discussion of & -participating in group \\
-public presentation & the project; & analysis and \\
\hline
\end{tabular}

\begin{tabular}{|c|c|c|}
\hline $\begin{array}{l}\text { of the project } \\
\text {-total feedback } \\
\text { (group and } \\
\text { individual } \\
\text { assessment of the } \\
\text { results and process } \\
\text { of the project } \\
\text { activity); } \\
\text {-examination of the } \\
\text { possible use of the } \\
\text { project results }\end{array}$ & $\begin{array}{l}\text { - self-analysis and } \\
\text { self-evaluation of } \\
\text { the process and } \\
\text { results of project } \\
\text { activities }\end{array}$ & $\begin{array}{l}\text { evaluation of the } \\
\text { project results; } \\
\text {-analyzing and } \\
\text { reasoning } \\
\text { assessments of student } \\
\text { reports; } \\
\text {-analyzing changes in } \\
\text { the competencies and } \\
\text { cognitive interests of } \\
\text { students; } \\
\text {-motivating students } \\
\text { (creating a sense of } \\
\text { success, emphasizing } \\
\text { the social importance); } \\
\text {-organizing the open } \\
\text { use of the results of } \\
\text { the project activity }\end{array}$ \\
\hline
\end{tabular}

\section{CONCLUSIONS}

The use of structural, functional and genetic aspects of system analysis allows to design a model project activity development. It includes both the "horizontal" advancement of students towards the goal on the basis of quantitative accumulation of personal activity opportunities and project implementation abilities, and the "vertical" progress as a transition from one level of the project activity development to the higher one. The highest form of project activity, as we mentioned earlier, is the independent cognitive activity.

Thus, the designed structural and functional model of the students' project skills development in the corporate educational interaction may be used as a guide for organizing this process, evaluating its completeness and quality. The model's effectiveness was proved by our experimental work at the higher stage of training. The study of the theoretical and practical aspects of the problem of project activity made it possible to define it as a form of corporate educational activity of students, involving the development and implementation of the personally and socially significant product that enriches the students' experience and contributes to their personal development.

\section{REFERENCES}

[1] G.Hegedủs, Projektpedagógia, Kecskeméti Föiskolai Tanítóképző Kar, Kecskemét, 2002

[2] M. Knoll, "The project method: It's vocational education origin and international development", in Journal of Industrial Teacher Education 34, 1997. 59-80 pp.

[3] Merriam-Webster Dictionary. https://www.merriamwebster.com/dictionary/project?src=search-dict-hed

[4] Buck Institute for Education (BIE). Introduction to project based learning. (2014). Retrieved from http://bie.org/images/uploads/general/ 20fa7d42c216e2ec171a212e97fd4a9e.pdf

[5] Hidden curriculum, in S. Abbott (Ed.), The glossary of education reform. (2014). Retrieved from http://edglossary.org/hidden-curriculum

[6] M. Füz-Kószó, and K. Szabó, "Learning it by doing: Project-based learning”, in "Mentor(h)áló 2.0 Program”, http://www.jgypk.hu/mentorhalo/tananyag/Tevekenyen az iskolaban/ind ex.html

[7] J.Spallino, Focus on project based learning: Evolving pedagogy in education, https://www.methodschools.org/blog/focus-on-project-basedlearning-evolving-pedagogy-in-education

[8] V.A. Shtoff, Modelling and philosophy, Moscow: Nauka, 1996.

[9] A.I. Uyemov, Logical basis of modeling, Moscow: Mysl', 1971.

[10] G.E. Muravyova, "On theory og educational processes projecting", in 
Pedagogical education and science, № 4, 2002, pp.14-21.

[11] M.F. Caro, D.P. Josyula, and J.A. Jimenes, "Multi-level pedagogical model for the personalization of pedagogical strategies in intelligent tutoring systems", in Dyna (Medellin, Colombia) 82(194), December 2015, pp. 185-193.

[12] R. Mizoguchi, Y. Hayashi, and J. Bourdeau, "Ontology-based formal modeling of the pedagogical world: Tutor modeling", in Adv. Intell. Tutoring Syst. 308, pp. 229-247, 2010. DOI: 10.1007/978-3-642-14363211

[13] B.F. Lomov, Methodological and theoretical problems of psychology,
Moscow: Nauka, 1984.

[14] S.L. Rubinshtein, Basis of psychology, St-Petersburgh, 1999.

[15] N.F. Talysina, Practical coursebook on pedagogical psychology, Moscow: Academy, 2002.

[16] L.B. Sokolova, "On deepening of approaches to understanding of pedadical activity”, in Credo, №2, 2006.

[17] G.I. Shchukina, The role of activity in educational process, Moscow: Prosvescheniye, 1986. 